\title{
Writing Argumentative Essay: How Far They Can Go?
}

\author{
Bayu Ramadhan \\ U-Raise Academy, Pekanbaru, Indonesia \\ bayu.rammadhan@gmail.com
}

\section{ARTICLE HISTORY \\ Received : 2019-07-16 \\ Revised : 2019-08-22 \\ Accepted : 2019-08-31}

\section{KEYWORDS}

\section{Writing}

Argumentative essay

English students

\begin{abstract}
Writing is very important for everyone to share their ideas, experiences and their thoughts into the written form. This present study tries to figure out and explore the university students in writing argumentative essay. Therefore, this present conducted a survey research to 21 students who produced argumentative essay from English department in Universitas Lancang Kuning (Unilak). The survey analysed the Content, Organization, Vocabulary, Grammar, Mechanics In order to answer the research question. The result of the research showed that the students' ability in argumentative essay was good regarding on the result of the test. This analysis of this present study found that the students' ability in argumentative essay was categorise $(96,55)$. This is means that these 21 students can go further on their academic journey regarding English when it needs an argumentative essay in written form.
\end{abstract}

\section{Introduction}

Writing is one of the English language skills that must be mastered by the students besides reading, listening and speaking. Writing is very important for the students because they can share their ideas, experiences and their thoughts into the written form; it is also needed because they can also transfer information and knowledge. Students can write letters, notes, essays, invitations, and any other written form to give information to the other people as the reader. Writing also needs time, thought, and many conscious choices to move from one first conception to public document. Writing can be extremely frustrating as writers want to turn vague ideas into a full statement that they want it to mean a completed statement, they may doubt that they have anything to say, but they will find that they are frequently mistaken. In other words, writing can be concluded as a tool of communication between the writer and the reader.

Nowadays, most of students are not interested in writing, because writing seems difficult for them. Writing is difficult because lack of vocabulary, organizing ideas, spellings, a coherent arrangement of words, clauses and sentences with the appropriate of grammar and structures. In vocabulary, students have a little vocabulary, so that they are getting difficulties in writing. It is hard for them to write since they still have lack of vocabulary. For the students who have a good motivation, it will not be a problem. However, it does not happen on the students who have low motivation. As the result, the ideas are not developed completely.
This study believes its necessary to find out students' ability in Writing Argumentative Essay to see how far they can go i.e., To avoid misunderstanding and misinterpretation, researcher defines some terms used in this research:

Moreover, ability is the power to do something physical or mental. Here means that ability is the student's capacity in composing something correctly and completely. According to Thompson (1993), argumentative essay is the arguments students present in support their position an argument not a simply a statement of opinion; it is an attempt to support their position with reasons. According to Hyland (2003), Writing is a way of sharing personal meanings and writing courses emphasizes the power of the individual to construct his or her own views on a top Education and Teachers Training, Universitas Lancang Kuning.

According to Jhonson (2008) writing is having ideas, organizing ideas and communicating ideas. In this sense, grammar, spelling and punctuation are a means to an end, but they are not ends by themselves. And Jhonson (2008) added that good writing is expresses ideas efficiently and effectively. It means writing is created clear, concise and short in expressing the ideas with attention to the creation of a sense of the text properly without overlook all the rules. Furthermore, Zamel (2007) states that writing is a process through which meaning is created. This suggests composition instruction that recognizes the importance of generating, formulating, and refining one's ideas. It means writing is the submission of ideas with a meaning by following the step instruction from beginning to end. So, the meaning is created looks great. 
According to Oshima (2006) writing is important to note that writing is a process, not a product. There are four main stages in writing process: prewriting, planning, writing, revising and writing the final copy to hand in. In the writing process, after prewriting and planning is writing and revising several drafts until have produced a final copy to hand in. After write the rough draft, the next step is revises it. And then, change what you have written in order to improve it. Check it over for content and organization, including unity, coherence and logic. You can change, rearrange, add or delete. All for the goal of communicating your thoughts are more clearly, more effectively and in more interesting way. The next step is to proofread your paper to check for grammar, sentence structure, spelling and punctuation. Now you are ready to write the final copy to hand in. It means to produce a good writing, needs to be done with the process: prewriting, planning, writing and revising drafts, and writing the final copy hand in. In the process of writing, it's able to follow the stages that have been defined so that we can produce a good writing with the process.

Writing is a complex combination of skills which is best taught by breaking down the process. The writing process involves a series of steps to follow in producing a finished piece of writing. Educators have found that by focusing on the process of writing, almost everyone learns to write successfully. There is process to do writing-which many writers follow naturally. According to Hyland (2003) there are ten processes in writing, there are as follow:

a) Selection of topic: by the teacher and/or students.

b) Prewriting: brainstorming, collecting data, note taking, and outlining.

c) Composing: getting ideas down on paper.

d) Response to draft: teacher/peers respond to ideas, organization, and style.

e) Revising: reorganizing, style, adjusting to readers, refining ideas.

f) Response to revisions: teacher/peers respond to ideas, organization, and style

g) Proofreading and editing: checking and correcting form, layout and evidence.

h) Evaluation: teacher evaluates progress over the process.

i) Publishing: by lass circulation or presentation, notice boards, website, etc.

j) Follow-up tasks: to address weaknesses.

According to Brown (2003), assessment is an ongoing process that encompasses a much wider domain. Whenever a student responds to a question, offers a comment, or tries a new word structure, the teacher subconsciously make an assessment of the student's performance.

In giving scores for writing activities especially in the argumentative essay, the researcher would like to use a rubric, they are: Content, Organization, Vocabulary, Grammar and Mechanics. There are some experts' definition on argumentative essays. Thompson (1993) argues that argumentative essay is the arguments students present in support their position an argument not a simply a statement of opinion; it is an attempt to support their position with reasons. This position is critical stance or thesis that take on her essay topic. They should be able to prove their thesis in one or two students in the first paragraph in their essay. They thesis states the conclusion is aim to prove. The argument they develop in the essay offers a set of reasons or evidence to support their conclusion.

Next, Konar (2009) states that the main purposes of writing argumentative essay is to convince readers that one's particular view opinion on a controversial issue is correct. In addition, at times one many have a second purpose for his/her argumentative essay; to persuade the audience to take some sort of action. From explanation above, it can be concluded that an argumentative essay is a piece of writing which contains about some facts and the evidence. In the argumentative essay, someone should be able to show their own argument toward the topics provided. While the main purposes of the argumentative essay is to persuade the readers or audience agree with their statement stated in the essay as well.

Generally, argumentative essay is a form of writing in which the writer argues for a certain idea and try to persuade readers to adopt the writer's point of view. Harvey (2003) also says that argumentative essay is the act of forming reasons, making orientations, drawing conclusions and applying them to the case in argument; the process of understanding propositions not known or admitted as true, from facts or principles known, admitted or proved true.

In addition, argumentative essays present one side of an issue using evidence to convince the readers to draw the same conclusions as the writer. In short, argumentative essay has been defined as a wellstructured and well-supported point of view on a topic that supported by reasons. Similar to the other essay, argumentative essay also has three essential parts. The introductory paragraph that functions as attention getter for the readers' then body paragraph where the writer actually proves the assertion at the end of the introduction and finally the concluding paragraph. It is in line with Jordan (1990) and Ozagac (2004) claim an academic essay, like argumentative essay, has three essential parts. The first paragraph of an essay is an introductory paragraph. It consists of general to specific statements and a thesis statement. The 
following paragraph is called body paragraph. It contains as many as paragraph as necessary to explain the controlling idea in the thesis statement in a logical sequence.

The last paragraph of the essay is concluding paragraph which give the readers the conclusion or the summary of the essay and the writer's final comments. This study presents some former researches in which the findings related to this research. Those are Anita (2012), Yuwanti (2014), Hidayati (2014), Febrianita (2012), Rahmatunisa (2014) and all of those researches were being reviewed on the following paragraphs. Anita (2012) with the research entitled "Students' Ability in Writing an Introductory Paragraph of Argumentative Essay", the data showed from 25 students, 8 students wrote the topic of Young Marriage, 4 students wrote the topic of Death Penalty in Indonesia, 6 students wrote the topic of Students Exchange Program and 7 students wrote the topic of Sex Education at School. From 25 students only one paper could not be analysed because the writer did not write argumentative essay but an explanation essay. Two writing lecturers as the scorer and the researcher herself analysed the data by using the same criteria.

From the average scores of the three scores, it was found that the ability of the students in writing general statements of an introductory paragraph of argumentative essay was good; it was about ten students $(41.67 \%)$ out of 24 students. While in writing thesis statement, the ability of the students in writing thesis statement of an introductory paragraph of argumentative essay was average; it was about nine students $(37.5 \%)$ out of 24 students. Yuwanti (2014) had done a research entitled "Error Analysis on the Argumentative Essays Written by the Fourth Semester Students of Study Program of English". In this study the researcher analysed errors in the argumentative essays written by them and the problems were: The errors found in the argumentative essay by the fourth semester students of English Department of Faculty of Cultural Studies of Brawijaya University, and the types of errors found in the argumentative essay by the fourth semester students of English Department Students of Faculty of Cultural Studies of Brawijaya University.

All kinds of errors mentioned by Dulay in the surface strategy taxonomy were made by the students, but the researcher found that the error mostly made was misformation (Mf) with 127 errors (44\%) especially misformation of "be". Other mistakes made were omission (Om) with 95 errors (33\%), then addition (Ad) with 57 errors (20\%), and the last is misordering (Md) with 9 errors $(3 \%)$. It can be concluded that when producing a written work like an essay, the students focused on the content more than on grammar. Misformation errors were made the most because in Bahasa Indonesia as the L1, the structure like 'be' or regular and irregular past tense verbs are not significant or not found.

Hidayati (2014) with a research entitled "Mistakes and Error Analysis of Cohesive Features in Argumentative Essay of Fifth Semester Students of English Department of Jambi University". From the result of the test, the researcher found that there were four types of errors namely misformation in using antonym, misformation in using personal pronoun and misformation in using possessive pronoun and omission of additional connective or conjunction. Meanwhile, the researcher found nine types of mistakes namely misformation in using personal pronoun, misformation in using possessive pronoun, misformation in using demonstrative reference, misformation in using additional conjunction, misformation in using cause effect conjunction, omission of additional conjunction, omission opposite conjunction, omission of cause effect conjunction, misformation in using noun substitution

Febrianita (2012) has conducted a research entitled "An Analysis of Parallel Structure Errors of Sentences in Students' Writing Argumentative Essay (Study at Third Year English Department Students at STKIP PGRI West Sumatra”. Based on the research, it could be seen that the students created the error in each class of in using making parallel sentence. The first error misformation was found in the noun, verb, adjective, and adverb class in which were 47(62\%) students who created error. The next was addition that found just two class of word, there are noun and verb class $15(20 \%)$ students creating the error. The third was omission which one just two class of word that found in this type error, that are noun and verb class $8(10 \%)$ students of this error. The last was misordering which one just in adjective class. There were only $6(8 \%)$ students who made the error. Thus, the most error was created in misformation.

Rahmatunisa (2014) with a research entitled "Problems Faced by Indonesian EFL Learners in Writing Argumentative Essay". It is carried out in a qualitative research design as it attempted to describe the problems and their ways out. The data were taken from university students' writing task and interview. The participants are the second year of university

Indonesia students who enrol their study in English Department. Results of the data indicated that Indonesian EFL learners faced the problems in three categories, those are linguistics problems, cognitive problems, and psychological problems. Mostly, students faced problems in linguistics related to the grammatical structure $(23.2 \%)$, formatting words $(30.2 \%)$, words classes $(16.3 \%)$, error in using words $(9.3 \%)$, and the use of article (21\%). Second, cognitive problems are related to organizing paragraph, difficulties in remaining word classes, getting lost the generic structure, making a conclusion, 
and putting punctuation. Last, psychological problems which included laziness, egoism, bad mood, and difficulties to start writing also faced by Indonesian EFL learners. Data analysis also indicated the problem solving which hopefully will be beneficial for EFL teachers in writing class. It is strongly recommended that the EFL class should strengthen all the language skills in general and writing in particular, motivate the students to use English with the teachers, introduce pair work, peer-correction, and use dictionaries frequently etc.

The difference between previous researches with this research is the focus of this research is on students' ability in writing argumentative essay third semester of students in English Department of Universitas Lancang Kuning. The process of writing argumentative essay will be on written test from the researcher. Meanwhile, this research will be focus on the students' written test.

\section{Method}

This survey design following Creswell (2012) ideas on what is survey research as "procedures in quantitative research in which investigators administer a survey to a sample or to entire population of people in order to describe the attitudes, opinions, behaviours, or characteristics of population". Based on the definition above, the researcher conducted this research to analyse students' ability in writing argumentative essay at English students in Universitas Lancang Kuning.

This research was conduct at the third semester students of English Education Department, Faculty of Education and Teachers Training, Universitas Lancang Kuning for Academic year 2018/2019. The researcher is chosen by who they have been studying their writing classes. Consequently, they can write good quality of essay particularly in writing a good argumentative essay. In this study, the population was the third-semester students of English Education Department, Faculty of Education and Teachers Training, Universitas Lancang Kuning consisting of three classes; Class A consists of 21 students, class B consists of 21 students and class C consists of 12 students. So, the total of the population is 54 students.

Sample was selected numbers of those representing the population of the research. Gay (2000) defines that sampling is the process of selecting a number of individuals for a study in such a way that they represent the larger group from which they are selected. In determining the sample, the researcher conducts probability sampling technique. Subjects are handpicked by the researcher on the basis of his or her own estimate of their typicality. In this case, the researcher determines to choose class B as the sample of this research after considering to the treatment that given by the lecturer while lecturing the course. The researcher believed that class B have the same treatment in learning writing course particularly about writing essay because they belong to the Regular Class which is taught by the same lecturer in the same day. So that, the researcher only took the sample from the regular class of the third semester students of English Education Department, Faculty of Teachers' Training and Education, Universitas Lancang Kuning. The researcher applied a writing test, to the topics that students want. The test is used when the researcher works on the inquiry of numbers using statistics in analysing the obtained data. This instrument is going to be used by the researcher to gain the data and identify the percentage and level of students'ability. Here, the students were asked to write 500 words in 1-2 hours' time allocation. To find out how students' ability in writing argumentative essay, a writing test is used to collect the data. The students are asked to write 500 words in 1-2 hours of time allocation. The students are then asked to collect the works after testing time is finished. The instruments result submitted by students was be assessed by two qualified writing scorer based on all aspects assessment of writing. The scores gained would be then analysed by the researcher. The researcher analysed the data in a few steps. Data were assessed using an assessment rubric adopted from Nababan, Nuraeni, and Sumardiono (2012). Argumentative essays that have rater values are calculated using the following formula:

$$
\mathrm{P}=\frac{x}{N} x 100 \%
$$

Where:

$$
\begin{aligned}
& \mathrm{P}=\text { Percentage } \\
& \mathrm{X}=\text { Number of frequency } \\
& \mathrm{N}=\text { The Number of Students }
\end{aligned}
$$

Furthermore, the researcher was consulted to the lecturer teaching writing course to obtain and refer to the scoring of students' performance. This study refers to the course syllabus. After conducting all the calculating process above, findings obtained could be then analysed to find out specifically toward the purpose of the research is. So, the finding could describe students' ability in using prepositions of direction.

\section{Findings}

In this section this study discussed the result of the study to answer the main research question was "How is the Students' Ability in Writing Argumentative Essay?" The data was taken by giving the test about Writing Argumentative Essay. The test was taken in January 2019. The researcher asked the students to write Argumentative Essay in their paper sheet and after that the researcher asked the rater to giving the assessment about the result of the test by using a rubric score. The rater asset the result of the 
test based on the five aspects there are content, Organization, vocabulary, grammar, mechanic. content is the first aspect, the rater conveys the criteria of the content on the essay of the students such as through development of topic, relevant to topic but lacks detail, Inadequate the development of topic, does not show knowledge of topic.

Organization is the second aspect, the rater conveys the criteria of the Organization on the essay of the students such as follow generic structures correctly, loosely organized but ideas stand out, incoherent ideas and lack logical sequencing, does not follow generic structures correctly. Vocabulary is the third aspect, the rater convey the criteria of the vocabulary on the essay of the students such as employ accurate and effective choice of words/diction (e/es), employ accurate diction, but not effective, employ lacks accuracy of diction, but meaning not obscured, errors in applying diction or word form, and meaning obscured. Grammar is the fourth aspect, the rater convey the criteria of the grammar on the essay of the students such as use correct grammar (simple present tense, adjective, subject-verb agreement, etc), several errors of tense, adjective, subject-verb agreement, etc, but meaning not obscured, major errors of tense, adjective, subject-verb agreement, etc, and meaning obscured, no mastery of sentence construction and dominated by errors. Moreover, mechanics is the fourth aspect, the rater convey the criteria of the mechanics on the essay of the students such as very little errors of mechanics, few errors of mechanics, but meaning not obscured, many errors of mechanics, and meaning obscured, Dominated by errors of mechanics can be seen in the table 3.1:

Table 3.1 The List of Percentage Students' Ability

\begin{tabular}{ccc}
\hline Aspect & Percentage & Quadrant \\
\hline Content & $25,24 \%$ & $91^{\circ}$ \\
Organization & $12,74 \%$ & $46^{\circ}$ \\
Vocabulary & $25,61 \%$ & $92^{\circ}$ \\
Grammar & $24,58 \%$ & $88^{\circ}$ \\
Mechanics & $11,84 \%$ & $43^{\circ}$ \\
\hline
\end{tabular}

Based on the table above we could see there were five aspects of the students' ability in Students' Ability in Writing Argumentative Essay. The first content, the percentage of the content was $25,24 \%$ and the quadrant was $91^{\circ}$. The second Organization, the percentage of the organization was $12,74 \%$ and the quadrant was $46^{\circ}$. The third vocabulary, the percentage of the vocabulary was $25,61 \%$ and the quadrant was $92^{\circ}$. The fourth grammar, the percentage of the grammar was $24,58 \%$ and the quadrant was $88^{\circ}$. And the last mechanics, the percentage of the mechanics was $11,84 \%$ and the quadrant was $43^{\circ}$.

\section{Discussion}

This research has conducted research at Teachers English Education Department Faculty of Education and Teachers Training, Universitas Lancang Kuning Pekanbaru, the participants were the third semester of the students. The researcher analysed the students' ability in writing argumentative essay because this research purposes to answer the research question. Based on the result of the research the researcher found the students' ability in writing argumentative essay at the third semester student has very good level it can be seen from the result of the score. Moreover, the table of the score can be seen the total score of the students was 96,55 it means that the students' ability in writing argumentative essay have very good level. The rubric score has five aspects there are content, organization, vocabulary, grammar, mechanics. The score for each aspect also have very good result. For the content the average of the score was 9,75 the second for the organization the average of the score was 4,92 the third for the vocabulary the average of the score was 9,89 the fourth for the grammar the average of the score was 9,49 the fifth for the mechanics tha average of the score was 4,57.

Based on the result of the score, it can be concluded that the students' ability in writing argumentative essay can be categorized in very good level. By comparing to previous researcher with this research is the focus of this research is on students' ability in writing argumentative essay at the third semester students of FKIP UNILAK Pekanbaru. The process of writing method was been on writing test from the researcher. Meanwhile, this research focused on the five aspects, content, organization, vocabulary, grammar, and mechanics.

The result of this research was analysed by using scoring rubric from Nababan (2012), the score was got from raters. This research also related to the findings that ever done before by Anita (2012) conducted the research entitled "Students' Ability in Writing an Introductory Paragraph of Argumentative Essay", from the average scores of the three scores, it was found that the ability of the students in writing general statements of an introductory paragraph of argumentative essay was good.

\section{Conclusion and Suggestion}

This study reveals the students abilty in writing argumentative essay have a very good score and very good level. The assessment employ five aspects i.e., content, organization, vocabulary, grammar, and mechanics. The content $(9,75)$, Organization $(4,92)$, Vocabulary $(9,89)$ Grammar (9,49), Mechanics $(4,57)$. This is means that these 21 students can go further on their academic journey regarding English when it needs an argumentative essay in written form. 
Based on the research, the researcher gives some suggestions about Students' Ability in Writing Argumentative Essay. The researcher suggests the students can learn more about how to write argumentative essay, the researcher suggests the students can learn more about five aspects in the writing such as content, Organization, vocabulary, grammar, mechanics, because this aspect will help us in writing, the researcher suggests this research can be useful for the next researcher.

\section{Acknowledgement}

The writers give their gratitude to anonymous reviewers and colleague who assisted immensely in the production of this research article, especially for their feedback and critic.

\section{References}

Anita, R. (2012). “Students' Ability in Writing an Introductory Paragraph of Argumentative Essay". STAIN Batusangkar.

Ansarimoghaddam, S., Hoon, T. B., \& Yong, M. F. (2017). Collaboratively Composing an

Argumentative Essay: Wiki versus Face-to-face Interactions. GEMA Online ${ }^{\circledR}$ Journal of Language Studies, 17(2).

Aull, L. (2017). Corpus analysis of argumentative versus explanatory discourse in writing task genres. Journal of Writing Analytics, 1.

Brown H, Douglas. (2003). Language Assessment: Principles and Classroom Practices. San Fransisco: PEARSON Longman.

Bychkovska, T., \& Lee, J. J. (2017). At the same time: Lexical bundles in L1 and L2 university student argumentative writing. Journal of English for Academic Purposes, 30, 38-52.

Creswell, W.J. (2012). Educational Research Planning,

Conducting, and Evaluating Quantitative and Qualitative Research. Fourth Edition. Boston: Pearson Education, Inc.

Crimmins, G., Nash, G., Oprescu, F., Liebergreen, M., Turley, J., Bond, R., \& Dayton, J. (2016). A written, reflective and dialogic strategy for assessment feedback that can enhance student/teacher relationships. Assessment \& Evaluation in Higher Education, 41(1), 141153.

Febrianita, A. (2012). "An Analysis of Parallel

Structure Errors of Sentences in Students' Writing Argumentative Essay (Study at Third Year English Department Students at STKIP PGRI West Sumatra". STKIP PGRI West Sumatra.
Gay, L.R. and Airasian, P. (2000). Education Reseach Competencies for Analysis and Application. (6th ed). New Jersey: Practice-Hall Inc.

Harvey, Michael. (2003). The Art of Argumentative Essay. Nuts and Botts of College Writing: Hacket Publishing.

Hasani, A. (2016). Enhancing Argumentative Writing Skill through Contextual Teaching and Learning. Educational Research and Reviews, 11(16), 15731578.

Hidayati. (2014). "Mistakes and Error Analysis of Cohesive Features in Argumentative Essay of Fifth Semester Students of English Department of Jambi University". Jambi University.

Ho, V., \& Li, C. (2018). The use of metadiscourse and persuasion: An analysis of first year university students' timed argumentative essays. Journal of English for Academic Purposes, 33, 53-68.

Hughes, Arthur. (2003). Testing For Language Teachers Second Edition. Cambridge University Press.

Hyland, Ken Et al. (2003). Second Language Writing. New York. Cambridge : University press

Jhonson, A. P. (2008). Teaching Reading and Writing: A Guidedbook For Tutoring and Remediating Students. USA: A Division of Rowman and Littlefield Publishers, Inc.

Jordan, R.R. (1990). Academic Writing Course. London: Collins \& Glasgow.

Konar, Nira. (2009). Communication Skils for Professional. Newdelhi: Raj press.

Krishnan, J., Cusimano, A., Wang, D., \& Yim, S. (2018). Writing together: Online synchronous collaboration in middle school. Journal of Adolescent \& Adult Literacy, 62(2), 163-173.

Lam, Y. W., Hew, K. F. T., \& Chiu, K. F. (2018). Improving argumentative writing: Effects of a blended learning approach and gamification. Language learning \& technology.

Li, M., \& Zhu, W. (2017). Good or bad collaborative wiki writing: Exploring links between group interactions and writing products. Journal of Second Language Writing, 35, 38-53.

Liu, L. (2005). Rhetorical education through writing instruction across cultures: A comparative analysis of select online instructional materials on argumentative writing. Journal of Second Language Writing, 14(1), 1-18.

Noroozi, O., Biemans, H., \& Mulder, M. (2016). Relations between scripted online peer feedback processes and quality of written 
argumentative essay. The Internet and Higher Education, 31, 2031.

Oshima, A., Hogue, A. (2006). Introduction to academic writing. White plains, NY: Pearson: Longman

Ozagac, Oya. (2004). Introducing Paragraphs and Thesis Statement. Pearson Education, Inc.

Rahmatunisa, A. (2014). "Problems Faced by Indonesian EFL Learners in Writing Argumentative Essay". University of Kuningan.

Schneer, D. (2014). Rethinking the argumentative essay. TESOL Journal, 5(4), 619-653.

Stab, C., \& Gurevych, I. (2017). Recognizing insufficiently supported arguments in argumentative essays. In Proceedings of the 15th Conference of the European Chapter of the Association for Computational Linguistics: Volume 1, Long Papers (pp. 980-990).

Thompson, E.P. (1993). Customs in Common. London: Penguin.

Wingate, U. (2012). 'Argument!'helping students understand what essay writing is about. Journal of English for academic purposes, 11(2), 145154.

Yuwanti, MC. (2014). "Error Analysis on the Argumentative Essays Written by the Fourth Semester Students of Study Program of English". University of Brawijaya.

Zamel, Vivian. (2007). Writing: The process of discovering meaning. Massachusetts/Boston: TESOL Quurterly.

Newell, G. E., Van Der Heide, J., \& Olsen, A. W. (2014). High school English language arts teachers' argumentative epistemologies for teaching writing. Research in the Teaching of English, 49(2), 95.

Stab, C., \& Gurevych, I. (2014, October). Identifying argumentative discourse structures in persuasive essays. In Proceedings of the 2014 Conference on Empirical Methods in Natural Language Processing (EMNLP) (pp. 46-56). 